\title{
PENGARUH PERHATIAN ORANG TUA DAN MOTIVASI BERPRESTASI TERHADAP PRESTASI BELAJAR FISIKA
}

\author{
Siwi Puji Astuti ${ }^{1}$, Santy Handayani ${ }^{2}$ \\ Program Studi Teknik Informatika, Universitas Indraprasta PGRI ${ }^{1}$ \\ Email: siwiunindra2012@gmail.com ${ }^{1}$ \\ Program Studi Teknik Informatika, Universitas Indraprasta PGRI² \\ Email: handayani_santy@gmail.com ${ }^{2}$
}

\begin{abstract}
Abstrak
Penelitian ini bertujuan untuk mengetahui pengaruh perhatian orang tua dan motivasi berprestasi terhadap prestasi belajar fisika. Hipotesis penelitian ini adalah 1) terdapat pengaruh perhatian orang tua dan motivasi berprestasi secara bersama-sama terhadap prestasi belajar fisika, 2) terdapat pengaruh perhatian orang tua terhadap prestasi belajar fisika, 3) terdapat pengaruh motivasi berprestasi terhadap prestasi belajar fisika. Metode yang digunakan dalam penelitian ini adalah metode survei dengan analisis regresi berganda. Populasi terjangkau adalah siswa/siswi kelas XI IPA tahun ajaran 2016/2017 di SMA Negeri Kecamatan Kramat Jati. Sampel penelitian berjumlah 74 siswa diperoleh dengan teknik random sampling yang diambil dari 2 sekolah SMA Negeri yang ada di Kecamatan Kramat Jati. Pengumpulan data dilakukan dengan kuesioner dan hasil rapor semester ganjil 2016/2017. Teknik analisa data penelitian menggunakan regresi ganda Uji- $F$ dan Uji-t. Uji persyaratan data menggunakan lima uji asumsi klasik. Hasil penelitian diperoleh kesimpulan 1) Terdapat pengaruh perhatian orang tua dan motivasi berprestasi secara bersama-sama terhadap prestasi belajar fisika, hasil analisis data menunjukkan nilai Sig $=0,000$ dan Fhitung $=$ $17,953,2)$ Terdapat pengaruh perhatian orang tua terhadap prestasi belajar fisika, hasil analisis data menunjukkan nilai $\mathrm{Sig}=0,037$ dan $\left.t_{\text {hitung }}=2,125,3\right)$ Terdapat pengaruh motivasi berprestasi terhadap prestasi belajar fisika, hasil analisis data menunjukkan nilai Sig $=0,000$ dan $t_{\text {hitung }}=5,053$.
\end{abstract}

Kata kunci: perhatian orang tua, motivasi berprestasi, prestasi belajar fisika

\begin{abstract}
The research is aimed at showing the effects of parental attention and achievement motivation on physics learning achievement. The hypotheses are 1) there are joint effects of parental attention and achievement motivation on physics learning achievement, 2) there is an effect of parental attention on physics learning achievement, 3) there is an effect of achievement motivation on physics learning achievement. The method used in this research is a survey method with multiple regression analysis. The population is students of class XI IPA of 2016/2017 school year in SMA Negeri in Kramat Jati, with 74 students from 2 SMA Negeri taken as the sample by applying the random sampling technique. The data are collected by distributing questionnaires and examining first-semester reports. The technique used in the data analysis is multiple regression F-Test and T-test. The data requirement test includes five classic assumption tests. In conclusion, the data analysis result shows that 1) there are joint effects of parental attention and achievement motivation on physics learning achievement, as proven by the value of Sig $=0.000$ and $\left.F_{\text {Observed }}=17.953,2\right)$ there is an effect of parental attention on the physics learning achievement, as proven by the value of Sig $=0.037$ and tobserved $=2.125$ and 3) there is an effect of achievement motivation on physics learning achievement, as proven by the value of Sig $=0.000$ and tobserved $=5.053$.
\end{abstract}

Keywords: parental attention, achievement motivation, physics learning achievement

\section{Pendahuluan}

Keluarga, masyarakat, dan pemerintah bersama-sama bertanggung jawab pada pendidikan. Hal ini disebabkan proses belajar mengajar terdapat komponen yang saling berkaitan antara guru dan siswa. Keluarga adalah lingkungan masyarakat terkecil yang merupakan 
lingkungan pendidikan primer yang bersifat fundamental, sehingga sangat berperan dalam pembentukan proses pembelajaran anak. Orang tua berperan sebagai pendidik yang pertama dalam keluarga. Peran orang tua sangat menentukan perkembangan anak karena orang tua memiliki ikatan batin yang kuat bagi anak. Selain itu, orang tua juga berperan dalam pembentukan karakter anak di kehidupannya. Semangat belajar seorang siswa sangat dipengaruhi oleh keluarga, dimana perhatian orang tua akan menimbulkan motivasi dari dirinya untuk menjadi pribadi yang lebih baik lagi.

Ketika melakukan aktivitas belajar, anak sangat membutuhkan perhatian orang tua, orang tua sebaiknya terus memberikan motivasi agar anaknya selalu semangat dalam belajarnya. Jika anak sedang belajar janganlah orang tua mengganggu, misalnya dengan menyuruh mengambil sesuatu apabila tidak terlalu penting, karena akaan membuat konsentrasi belajar anak menjadi terganggu. Sebaiknya anak diberikan tempat belajar yang nyaman dan tentram untuk belajar.

Motivasi belajar bagi siswa merupakan faktor terpenting bagi keberhasilan dalam mencapai tujuan pembelajaran. Karena dengan adanya motivasi akan menumbuhkan semangat belajar dan rasa senang terhadap apa yang dipelajari. Motivasi belajar dapat berupa dorongan internal dan eksternal pada siswa yang sedang belajar untuk mengadakan perubahan tingkah laku, pada umumnya dengan beberapa indikator atau unsur yang mendukung. Dorongan internal dapat muncul dari diri sendiri, sedangkan dorongan eksternal dapat muncul dari luar diri seperti perhatian orang tua.

Perhatian dapat dikategorikan sebagai stimulus dari luar dalam peningkatan prestasi belajar siswa, dan yang tak kalah pentingnya adalah stimulus dari dalam siswa itu sendiri, yaitu motivasi siswa untuk berprestasi. Motivasi berprestasi merupakan dorongan yang ada dalam diri siswa untuk membuat dirinya berprestasi.

Berdasarkan latar belakang di atas, maka tujuan penelitian ini dapat diuraikan sebagai berikut: 1) untuk mengetahui pengaruh perhatian orang tuadan motivasi berprestasi secara bersama-sama terhadap prestasi belajar fisika, 2) untuk mengetahui pengaruh perhatian orang tua terhadap prestasi belajar fisika, 3) untuk mengetahui pengaruh motivasi berprestasi terhadap prestasi belajar fisika. Ketiga sumber data tersebut didasarkan pada tiga variabel penelitian, yakni data tentang variabel bebas $\left(\mathrm{X}_{1}\right)$ yaitu perhatian orang tua, variabel bebas $\left(\mathrm{X}_{2}\right)$ yaitu motivasi berprestasi, dan variabel terikat $(\mathrm{Y})$ yaitu prestasi belajar fisika. Maka hipotesis penelitian yang akan diuji dalam penelitian ini dirumuskan sebagai berikut: 1) terdapat pengaruh perhatian orang tua dan motivasi berprestasi secara bersama-sama terhadap prestasi belajar fisika, 2) terdapat pengaruh perhatian orang tua terhadap prestasi belajar fisika, 3) terdapat pengaruh motivasi berprestasi terhadap prestasi belajar fisika.

\section{Tinjauan Pustaka}

\section{Prestasi Belajar Fisika}

Belajar adalah proses perubahan tingkah laku yang disengaja berdasarkan pengalaman yang bukan semata-mata sikap dan nilai tetapi juga penguasaan pengetahuan dan keterampilan. Belajar dalam pengertian luas dapat diartikan sebagai kegiatan psikofisik menuju ke perkembangan pribadi seutuhnya. Kemudian dalam arti sempit, belajar dimaksudkan sebagai usaha penguasaan meteri ilmu pengetahuan yang merupakan sebagian kegiatan menuju terbentuknya kepribadian seutuhnya (Sardiman, 2011: 22).

Sedangkan menurut Good dan Brophy yang di kutip Uno (2008: 15), menyatakan bahwa belajar adalah suatu proses atau interaksi yang dilakukan seseorang dalam memperoleh sesuatu yang baru dalam bentuk perubahan perilaku sebagai hasil dari pengalaman itu sendiri (belajar). Perubahan perilaku tersebut tampak dalam penguasaan siswa pada pola-pola 
tanggapan (respon) baru terhadap lingkungannya yang berupa keterampilan (skill), kebiasaan (habit), sikap atau pendirian (attitude), kemampuan (ability), pengetahuan (knowledge), pemahaman (understanding), emosi (emosional), apresiasi (appreciation), jasmani dan etika atau budi pekerti, serta hubungan sosial. Seorang telah belajar jika tingkah lakunya telah berubah sebagai akibat pengalamannya. Perubahan tingkah laku tersebut bersifat relatif tetap dan bukan secara kebetulan atau keadaan sementara.

Syah (2008 : 141), menyatakan bahwa "prestasi belajar merupakan hasil dari sebagian faktor yang mempengaruhi proses belajar secara keseluruhan". Prestasi belajar adalah hasil atau taraf kemampuan yang telah dicapai siswa setelah mengikuti proses belajar mengajar dalam waktu tertentu baik berupa perubahan tingkah laku, keterampilan serta pengetahuan dan kemudian akan diukur dan dinilai yang kemudian diwujudkan dalam angka atau pernyataan. Berdasarkan teori dan penjelasan di atas dapat disimpulkan bahwa prestasi belajar fisika adalah kemampuan siswa dalam menguasai materi pokok fisika setelah melakukan proses pembelajaran fisika yang dicatat pada setiap akhir semester di dalam buku laporan atau disebut rapor. Prestasi belajar fisika juga dapat dilihat dari pemahaman siswa dalam menyelesaikan soal-soal yang berkaitan dengan fisika serta dapat menerapkan materi-materi fisika dalam kehidupan sehari-hari.

\section{Perhatian Orang Tua}

Perhatian merupakan pemusatan psikis, salah satu aspek psikologis yang tertuju pada suatu objek yang datang dari dalam dam luar diri individu. Dengan perhatian dapat digunakan untuk meramalkan tingkah laku atau perbuatan manusia dalam kehidupan sehari-hari. Perhatian akan memberikan warna dan corak bahkan arah tingkah laku seseorang. Dengan perhatian, seseorang akan mendapatkan gambaran kemungkinan rangsangan yang akan timbul sebagai respon terhadap masalah atau keadaan yang dihadapkan kepadanya. Suryabrata (2008: 14), menyatakan bahwa "perhatian adalah banyak sedikitnya kesadaran yang menyertai sesuatu aktivitas yang dilakukan". Sedangkan menurut Walgito (2010: 101) "perhatian merupakan pemusatan atau konsentrasi dari seluruh aktivitas yang ditunjukkan pada suatu kelompok atau objek".

Menurut Kamus Besar Bahasa Indonesia (2006: 802) orang tua adalah "ayah ibu kandung, orang yang dianggap tua, orang yang dihormati. Dari penjelasan tersebut dapat diambil kesimpulan bahwa pengertian orang tua dalam penelitian ini adalah ayah dan ibu dari anak (jika anak itu tinggal bersama ayah dan ibu) atau orang lain yang bertanggung jawab atas pendidikan anak tersebut/wali siswa/orang tua asuh atau jika anak tersebut tinggal bersama wali. Dari pengertian di atas, dapat dimaknai bahwa perhatian orang tua adalah pengerahan atau pemusatan tenaga/kekuatan jiwa dari orang tua terhadap aktivitas belajar anaknya dengan penuh kesadaran demi mencapai prestasi maksimal anak dalam belajar.

Anak sangat membutuhkan perhatian orang tua ketika melakukan aktivitas belajar. Perhatian yang diberikan bisa berbagai macam bentuknya, seperti memberikan motivasi supaya anaknya selalu semangat saat belajar, menemani anaknya belajar, membantu memberi jawaban bila ada pertanyaan yang tidak bisa dijawab oleh anak ketika belajar, jika perlu anak diberikan tempat belajar yang nyaman dan tentram untuk belajar. Sebaiknya jika anak sedang belajar janganlah orang tua mengganggu, misalnya dengan menyuruh mengambil sesuatu apabila tidak terlalu penting, karena akan membuat konsentrasi belajar anak menjadi terganggu.

\section{Motivasi Berprestasi}

Hakikat motivasi belajar adalah dorongan internal dan eksternal pada siswa yang sedang belajar untuk mengadakan perubahan tingkah laku, pada umumnya dengan beberapa 
indikator atau unsur yang mendukung. Hal itu mempunyai peranan besar dalam keberhasilan seseorang dalam belajar.

Konsep motivasi berprestasi pertama kali dipopulerkan oleh Mc. Celland (dalam Djaali, 2013: 107) yang mengemukakan bahwa "di antara kebutuhan manusia terdapat tiga macam kebutuhan, yaitu kebutuhan untuk berprestasi, kebutuhan untuk berafiliasi, dan kebutuhan untuk memperoleh makanan". Sementara itu, Hechausen (dalam Djaali, 2013: 103) juga mengemukakan bahwa, "motivasi berprestasi adalah suatu dorongan yang terdapat dalam diri siswa yang selalu berusaha atau berjuang untuk meningkatkan atau memelihara kemampuan setinggi mungkin dalam semua aktivitas dengan menggunakan standar keunggulan".

Menurut Kamus Besar Bahasa Indonesia (2006: 593), "motivasi adalah dorongan yang timbul pada diri seseorang sadar atau tidak sadar untuk melakukan suatu tindakan dengan tujuan tertentu". Berdasarkan teori dan pendapat tentang motivasi berprestasi maka diperoleh kesimpulan bahwa motivasi berprestasi adalah dorongan pada diri seseorang baik itu dari dalam ataupun dari luar untuk melakukan aktivitas belajar dan aktivitas lainnya dengan semaksimal mungkin, dan bersaing berdasarkan standar keunggulan agar mencapai prestasi dengan predikat terpuji atau predikat unggul.

\section{Metodologi Penelitian}

Metode penelitian yang digunakan dalam penelitian ini adalah metode survei. Teknik analisis yang digunakan adalah analisis regresi dan korelasi ganda. Penelitian ini dilaksanakan di SMA Negeri 93 Jakarta dan SMA Negeri 51 Jakarta, pada semester ganjil 2016/2017. Jumlah sampel dalam penelitian ini sebanyak 74 siswa yang dipilih dengan teknik Slovin. Hubungan antara ketiga variabel tersebut dapat digambarkan sebagai berikut:

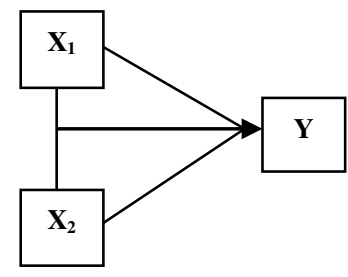

Keterangan :

$\mathrm{X}_{1}$ : Perhatian Orang Tua

$\mathrm{X}_{2}$ : Motivasi Berprestasi

Y : Prestasi Belajar Fisika

\section{Gambar 1. Desain Penelitian}

Sebagaimana dijelaskan di atas, bahwa ada tiga jenis data yang dikumpulkan dalam penelitian ini. Ketiga sumber data tersebut didasarkan pada tiga variabel penelitian, yakni data tentang variabel bebas $\left(\mathrm{X}_{1}\right)$ yaitu perhatian orang tua, variabel bebas $\left(\mathrm{X}_{2}\right)$ yaitu motivasi berprestasi, dan variabel terikat $(\mathrm{Y})$ yaitu prestasi belajar fisika yang dikumpulkan dengan menggunakan kuesioner atau angket dan nilai rapor semester ganjil tahun ajaran 2016/2017 yang diperoleh dari dokumen sekolah sekolah.

Sebelum kuesioner dijadikan alat pengumpul data, terlebih dahulu diadakan analisis instrumen, melalui uji coba instrumen yang terdiri dari uji validitas dan uji reliabilitas, dimaksudkan mengetahui kelayakan instrumen untuk dijadikan sebagai instrumen penelitian.

\section{Hasil dan Pembahasan \\ Deskripsi Data}

Berdasarkan hasil pengolahan data gambaran deskripsi statistik dari hasil perhitungan dan pengujian yang dilakukan dengan bantuan komputer melalui program aplikasi SPSS 16, seperti pada tabel berikut: 
Tabel 1. Deskripsi Data Penelitian

\begin{tabular}{llrrr}
\hline & & $\begin{array}{c}\text { Perhatian } \\
\text { Orang Tua }\end{array}$ & $\begin{array}{c}\text { Motivasi } \\
\text { Berprestasi }\end{array}$ & $\begin{array}{c}\text { Prestasi } \\
\text { Belajar Fisika }\end{array}$ \\
\hline $\mathrm{N}$ & Valid & 74 & 74 & 74 \\
& Missing & 0 & 0 & 0 \\
Mean & & 95 & 108.284 & 81.878 \\
Median & 94 & 109.5 & 82 \\
Mode & 90 & 105 & 80 \\
Std. Deviation & 6.366 & 11.300 & 5.630 \\
Minimum & 84 & 79 & 68 \\
Maximum & 110 & 130 & 92 \\
\hline
\end{tabular}

Data prestasi belajar siswa pada pelajaran fisika yang diperoleh dari para responden mempunyai rata-rata 81,88 dengan median sebesar 82,00, modus 80,00, skor minimum 68 dan skor maksimum 92. Hal ini menunjukkan bahwa rata-rata prestasi belajar fisika dari responden termasuk tinggi. Skor simpangan baku 5,63 atau sama dengan 6,87\% dari ratarata, dapat disimpulkan bahwa data skor skala prestasi belajar fisika dalam penelitian ini memiliki sebaran yang cenderung normal.

Data perhatian orang tua yang diperoleh dari para responden mempunyai rata-rata 95,00 dengan median sebesar 94,00, modus 90,00, skor minimum 84 dan skor maksimum 110 . Hal ini menunjukkan bahwa rata-rata prestasi belajar fisika dari responden termasuk tinggi. Skor simpangan baku 6,366 atau sama dengan 6,7\% dari rata-rata, dapat disimpulkan bahwa data skor perhatian orang tua dalam penelitian ini memiliki sebaran yang cenderung normal. Data motivasi berprestasi yang diperoleh dari para responden mempunyai rata-rata 108,28 dengan median sebesar 109,50, modus 105,00, skor minimum 79 dan skor maksimum 130. Hal ini menunjukkan bahwa rata-rata prestasi belajar fisika dari responden termasuk tinggi. Skor simpangan baku 11,3 atau sama dengan 10,43\% dari rata-rata, dapat disimpulkan bahwa data skor motivasi berprestasi dalam penelitian ini memiliki sebaran yang cenderung normal.

\section{Pengujian Persyaratan Analisis}

Penelitian ini menggunakan lima uji asumsi klasik, yaitu: uji normalitas, uji multikolinearitas, uji heteroskedastisitas, uji normalitas galat/residual, dan uji linearitas dengan menggunakan program SPSS for windows versi 16.

\section{Uji Normalitas}

Tabel 2. Hasil Uji One-Sample Kolmogorov Smirnov

\begin{tabular}{llrrr}
\hline & & $\begin{array}{c}\text { Perhatian } \\
\text { Orang Tua }\end{array}$ & $\begin{array}{c}\text { Motivasi } \\
\text { Berprestasi }\end{array}$ & $\begin{array}{c}\text { Prestasi Belajar } \\
\text { Fisika }\end{array}$ \\
\hline N & 74 & 74 & 74 \\
Normal Parameters & & & \\
& Mean & 95 & 108.28 & 81.88 \\
Most Extreme & Std. Deviation & 6.366 & 11.3 & 5.63 \\
Differences & Absolute & 0.11 & 0.088 & 0.126 \\
& Positive & 0.11 & 0.074 & 0.117 \\
Kolmogorov-Smirnov Z & Negative & -0.07 & -0.088 & -0.126 \\
Asymp. Sig. (2-tailed) & & 0.945 & 0.76 & 1.085 \\
& & 0.334 & 0.611 & 0.19 \\
\hline
\end{tabular}

a. Test distribution is Normal. 
Berdasarkan hasil perhitungan yang diperoleh terlihat bahwa nilai pada kolom Sig pada metode Kolmogorov-Smirnov untuk perhatian orang tua sebesar 0,334, motivasi berprestasi 0,611 dan prestasi belajar fisika 0,190. Berdasarkan hal tersebut maka nilai Sig untuk semua sampel lebih besar dari 0,05 (sig > 0,05). Dengan kata lain bahwa data dari semua sampel pada penelitian ini berdistribusi normal.

\section{Uji Multikolinearitas}

Tabel 3. Hasil Uji Multikolinearitas

\begin{tabular}{llrc}
\hline & & \multicolumn{2}{c}{ Collinearity Statistics } \\
Model & & Tolerance & VIF \\
\hline 1 & Perhatian Orang Tua & 0.959 & 1.043 \\
& Motivasi Berprestasi & 0.959 & 1.043 \\
\hline
\end{tabular}

a. Dependent Variable: Prestasi Belajar Fisika

Besar VIF untuk $\mathrm{X}_{1}$ dan $\mathrm{X}_{2}$ sebesar 1,043 dan tolerance 0,959 berarti $\mathrm{X}_{1}$ dan $\mathrm{X}_{2}$ tidak mempunyai problem multikolinieritas. Berdasarkan angka yang ditunjukkan VIF maka dapat disimpulkan bahwa nilai tersebut dapat dianggap tidak terjadi multicollinerity. Berdasarkan hal tersebut maka pengujian hipotesis data dilakukan denga analisis regresi berganda.

\section{Uji Heteroskedastisitas}

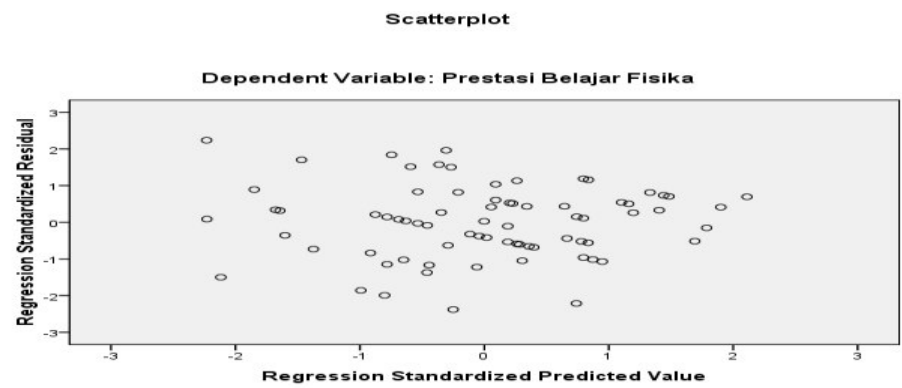

Gambar 2. Scatterplot

Grafik scatterplot di atas menunjukkan bahwa titik-titik menyebar secara acak dan tidak membentuk pola-pola tertentu yang jelas, serta tersebar di atas maupun di bawah angka 0 pada sumbu Y. Hal ini menunjukkan bahwa tidak terjadi heteroskedatisitas pada model regresi tersebut. Sehingga dapat dipakai untuk mendeteksi variabel prestasi belajar fisika berdasarkan perhatian orang tua dan motivasi berprestasi.

\section{Uji Normalitas Galat/Residual}

Tabel 4. Hasil Uji Normalitas Galat

\begin{tabular}{llr}
\hline & & $\begin{array}{c}\text { Unstandardized } \\
\text { Residual }\end{array}$ \\
\hline $\mathrm{N}$ & Mean & 74 \\
Normal Parameters & & \\
& Std. & 0 \\
Most Extreme & Deviation & 4.588 \\
Differences & Absolute & 0.051 \\
& Positive & 0.038 \\
Kolmogorov-Smirnov Z & Negative & -0.051 \\
Asymp. Sig. (2-tailed) & & 0.443 \\
\hline
\end{tabular}

a. Test distribution is Normal. 
Berdasarkan data statistik pada Tabel 4, menunjukkan bahwa uji hipotesis yang menyatakan distribusi residual pada analisis regresi ini mengikuti distribusi normal dapat diterima. Hal ini ditunjukkan dengan nilai Kolmogorov-Smirnov $Z=0,443$ dan sig 0,99>0,05. Hal ini berarti asumsi atau persyaratan analisis regresi terpenuhi.

\section{Uji Linearitas}

Pada Tabel 5 di bawah terlihat bahwa nilai pada kolom Sig baris Deviation fromLinierity adalah sebesar 0,689 lebih besar dari 0,05. Dengan kata lain bahwa garis regresi antara varibel $\mathrm{X}_{1}$ dan variabel $\mathrm{Y}$ tersebut adalah berpola linier.

Tabel 5. Hasil Pengujian Linieritas Garis Regresi Pengaruh $X_{1}$ terhadap $Y$

\begin{tabular}{lllrc}
\hline & & F & Sig. \\
\hline Prestasi Belajar Fisika & Between Groups & (Combined) & 1.092 & 0.386 \\
& & Linearity & 7.3 & 0.009 \\
& & $\begin{array}{l}\text { Deviation from } \\
\text { Linearity }\end{array}$ & 0.823 & 0.689 \\
& Within Groups & & & \\
& Total & & & \\
\hline
\end{tabular}

Pada Tabel 6 di bawah terlihat bahwa nilai pada kolom Sig baris Deviation from Linierity adalah sebesar 0,456 lebih besar dari 0,05. Dengan kata lain bahwa garis regresi antara varibel $\mathrm{X}_{1}$ dan variabel $\mathrm{Y}$ tersebut adalah berpola linier.

Tabel 6. Hasil Pengujian Linieritas Garis Regresi Pengaruh $X_{2}$ terhadap $Y$

\begin{tabular}{lllrr}
\hline & & F & \multicolumn{1}{c}{ Sig. } \\
\hline Prestasi Belajar Fisika & Between Groups & (Combined) & 1.923 & 0.25 \\
& & Linearity & 30.375 & 0.000 \\
& & $\begin{array}{l}\text { Deviation from } \\
\text { Linearity }\end{array}$ & 1.033 & 0.456 \\
& Within Groups & & & \\
& Total & & & \\
\hline
\end{tabular}

\section{Pengujian Hipotesis}

Hasil perhitungan dan pengujian bisa dilihat pada Tabel berikut :

Tabel 7. Koefisien Determinasi

\begin{tabular}{lcccr}
\hline Model & $\mathbf{R}$ & $\begin{array}{c}\mathbf{R} \\
\text { Square }\end{array}$ & $\begin{array}{c}\text { Adjusted R } \\
\text { Square }\end{array}$ & $\begin{array}{c}\text { Std. Error of } \\
\text { the Estimate }\end{array}$ \\
\hline 1 & $.580 \mathrm{a}$ & 0.336 & 0.317 & 4.652 \\
\hline a. Predictors: (Constant), Motivasi Berprestasi, Perhatian Orang Tua \\
b. Dependent Variable: Prestasi Belajar Fisika
\end{tabular}

Dari Tabel 7 di atas terlihat bahwa koefisien korelasi ganda pengaruh variabel bebas perhatian orang tua $\left(\mathrm{X}_{1}\right)$ dan motivasi berprestasi $\left(\mathrm{X}_{2}\right)$ secara bersama-sama terhadap prestasi belajar fisika (Y) adalah sebesar 0,58. Dari perhitungan tersebut di peroleh bahwa koefisien korelasi tersebut signifikan, dengan kata lain bahwa terdapat pengaruh yang signifikan variabel bebas perhatian orang tua $\left(\mathrm{X}_{1}\right)$ dan motivasi berprestasi $\left(\mathrm{X}_{2}\right)$ secara bersama-sama terhadap prestasi belajar fisika (Y). Koefisien determinasinya sebesar 33,6\% menunjukkan bahwa besarnya 
kontribusi perhatian orang tua dan motivasi berprestasi secara bersama-sama terhadap prestasi belajar fisika adalah sebesar $33,6 \%$, sisanya $(66,4 \%)$ karena pengaruh faktor lain.

\section{Tabel 8. Signifikansi Hubungan Perhatian Orang Tua dan Motivasi Berprestasi terhadap Prestasi Belajar Fisika}

\begin{tabular}{llrrrrr}
\hline Model & & $\begin{array}{c}\text { Sum of } \\
\text { Squares }\end{array}$ & \multicolumn{1}{c}{ df } & $\begin{array}{c}\text { Mean } \\
\text { Square }\end{array}$ & \multicolumn{1}{c}{ F } & Sig. \\
\hline 1 & Regression & 777.157 & 2 & 388.579 & 17.953 & $.000^{\mathrm{a}}$ \\
& Residual & 1536.748 & 71 & 21.644 & & \\
& Total & 2313.905 & 73 & & & \\
\hline
\end{tabular}

a. Predictors: (Constant), Motivasi Berprestasi, Perhatian Orang Tua

b. Dependent Variable: Prestasi Belajar Fisika

Hipotesis penelitian ini adalah:

$\mathrm{H}_{0}: \beta_{1}=\beta_{2}=0$

$\mathrm{H}_{1}: \beta_{1} \neq 0$ dan $\beta_{2} \neq 0$

Artinya:

$\mathrm{H}_{0}$ : tidak terdapat pengaruh perhatian orang tua dan motivasi berprestasi secara bersamasama terhadap prestasi belajar fisika.

$\mathrm{H}_{1}$ : terdapat pengaruh perhatian orang tua dan motivasi berprestasi secara bersama-sama terhadap prestasi belajar fisika.

Kriteria pengujian:

$F$ hitung $>F_{\text {tabel }}, \mathrm{H}_{0}$ ditolak $\mathrm{H}_{1}$ diterima.

$F$ hitung $<F_{\text {tabel }}, \mathrm{H}_{0}$ diterima $\mathrm{H}_{1}$ ditolak.

Dari Tabel 8 terlihat bahwa $F_{\text {hitung }}=17,953$, sedangkan $F_{\text {tabel }}=3,13$. Karena $F_{\text {hitung }}>F_{\text {tabel }}$ maka $\mathrm{H}_{0}$ ditolak yang berarti bahwa koefisien regresi tersebut signifikan. Berarti bahwa terdapat pengaruh signifikan variabel bebas perhatian orang tua $\left(\mathrm{X}_{1}\right)$ dan motivasi berprestasi $\left(\mathrm{X}_{2}\right)$ secara bersama-sama terhadap prestasi belajar fisika $(\mathrm{Y})$.

Tabel 9. Uji Signifikasi Koefisien Regresi Ganda

\begin{tabular}{llcccccc}
\hline & & \multicolumn{2}{c}{$\begin{array}{c}\text { Unstandardized } \\
\text { Coefficients }\end{array}$} & $\begin{array}{c}\text { Standardized } \\
\text { Coefficients }\end{array}$ & & \\
Model & & \multicolumn{1}{c}{$\begin{array}{c}\text { Std. } \\
\text { Error }\end{array}$} & Beta & t & Sig. \\
\hline 1 & (Constant) & 37.312 & 8.921 & & 4.183 & 0.000 \\
& Perhatian Orang Tua & 0.186 & 0.087 & 0.21 & 2.125 & 0.037 \\
& Motivasi Berprestasi & 0.249 & 0.049 & 0.499 & 5.053 & 0.000 \\
\hline
\end{tabular}

a. Dependent Variable: Prestasi Belajar Fisika

Menguji hipotesis keberartian koefisien regresi parsial masing-masing sebagai berikut:

Menguji keberartian koefisien regresi $b_{1}$ :

Hipotesis yang di uji:

$\mathrm{H}_{0}: \beta_{1}=0$

$\mathrm{H}_{1}: \beta_{1} \neq 0$

Terlihat $t_{\text {hitung }}<t_{\text {tabel }}$ yaitu $2,125>2,021 \mathrm{H}_{0}$ ditolak $\mathrm{H}_{1}$ diterima, berarti terdapat pengaruh yang signifikan variabel bebas $\mathrm{X}_{1}$ (perhatian orang tua) terhadap variabel terikat $\mathrm{Y}$ (prestasi belajar fisika).

Menguji keberartian koefisien regresi $b_{2}$ : 
Hipotesis yag di uji:

$\mathrm{H}_{0}: \beta_{2}=0$

$\mathrm{H}_{1}: \beta_{2} \neq 0$

Terlihat $t_{\text {hitung }}>t_{\text {tabel }}$ yaitu $5,053>2,021 \mathrm{H}_{0}$ ditolak $\mathrm{H}_{1}$ diterima berarti terdapat pengaruh yang signifikan variabel bebas $\mathrm{X}_{2}$ (motivasi berprestasi) terhadap variabel terikat $\mathrm{Y}$ (prestasi belajar fisika). Persamaan garis regresi $\widehat{Y}=37,312+0,186 \mathrm{X}_{1}+0,249 \mathrm{X}_{2}$ yang berarti bahwa kenaikan satu nilai perhatian orang tua maka akan terdapat kenaikan prestasi belajar fisika sebesar 0,186 dan setiap ada kenaikan satu nilai motivasi berprestasi maka akan terdapat kenaikan prestasi belajar fisika sebesar 0,249.

\section{Pembahasan}

Penelitian ini bertujuan untuk: 1) mengetahui pengaruh perhatian orang tua dan motivasi berprestasi secara bersama-sama terhadap prestasi belajar fisika, 2) mengetahui pengaruh parsial perhatian orang tuaterhadap prestasi belajar fisika, dan 3) mengetahui pengaruh parsial motivasi berprestasi terhadap prestasi belajar fisika.

\section{Pengaruh Perhatian Orang Tua dan Motivasi Berprestasi secara Bersama-sama terhadap Prestasi Belajar Fisika}

Berdasarkan Tabel 7 diperoleh koefisien korelasi sebesar 0,58 dan koefisien determinasi sebesaar $33,6 \%$, setelah dilakukan pengujian dengan program SPSS 16 terbukti bahwa koefisien korelasi tersebut signifikan. Hal ini berarti bahwa terdapat pengaruh variabel bebas $\mathrm{X}_{1}$ (perhatian orang tua) dan $\mathrm{X}_{2}$ (motivasi berprestasi) secara bersama-sama terhadap variabel terikat $\mathrm{Y}$ (prestasi belajar fisika).

Sedangkan dari analisis regresi diperoleh persamaan garis regresi $\widehat{Y}=37,312+0,186 \mathrm{X}_{1}+$ $0,249 \mathrm{X}_{2}$. Nilai konstanta $=37,312$ yang diperoleh pada tabel 9 menunjukkan bahwa dengan perhatian orang tua dan motivasi berprestasi paling rendah, sulit bagi siswa meraih prestasi belajar fisika yang baik, sedangkan nilai koefisien regresi sebesar 0,186dan 0,249 menunjukkan bahwa terdapat pengaruh positif variabel bebas $X_{1}$ (perhatian orang tua) dan $\mathrm{X}_{2}$ (motivasi berprestasi) secara bersama-sama terhadap variabel terikat $\mathrm{Y}$ (prestasi belajar fisika). Angka koefisien regresi tersebut juga menunjukkan bahwa setiap ada kenaikan satu nilai perhatian orang tua maka akan terdapat kenaikan prestasi belajar fisika sebesar 0,186 dan setiap ada kenaikan satu nilai motivasi berprestasi maka akan terdapat kenaikan prestasi belajar fisika sebesar 0,249 .

Menurut sintesis teori, perhatian orang tua adalah kecenderungan keaktifan perhatian orang tua yang dikerahkan untuk memberikan motivasi atau dorongan yang positif terhadap anaknya dalam usaha mencapai prestasi belajar yang seoptimal mungkin. Motivasi berprestasi merupakan suatu usaha yang mendorong seseorang untuk bersaing dengan standar keunggulan, dimana standar keunggulan ini dapat berupa kesempurnaan tugas, dapat diri sendiri atau prestasi orang lain. Sedangkan prestasi belajar fisika adalah kemampuan siswa dalam menguasai materi pokok fisikan(memahamidan dapat menjelaskan serta menyelesaikan soal-soal yang serta dapat menerapkan materi dalam kehidupan sehari-hari) setelah melakukan proses pembelajaran fisika yang yang dicatat pada setiap akhir semester di dalam buku laporan yang disebut rapor.

Dari uraian teoritis tersebut bisa diasumsikan bahwa semakin tinggi perhatian orang tua dengan diikuti motivasi berprestasi yang tinggi maka akan semakin tinggi pula prestasi belajar fisikanya dalam pencapaian pengetahuan, keterampilan, dan sikap dalam mata pelajaran fisika. Berdasarkan informasi kuantitatif dan teori tersebut peneliti berkesimpulan 
bahwa terdapat pengaruh perhatian orang tua dan motivasi berprestasi secara bersama-sama terhadap prestasi belajar fisika.

\section{Pengaruh Perhatian Orang Tua terhadap Prestasi Belajar Fisika}

Berdasarkan Tabel 9 pengujian hipotesis diperoleh bahwa nilai $t_{\text {hitung }}=2,125$ dan $\mathrm{Sig}=0,037$. Karena nilai $\mathrm{Sig}<0,05$ maka $\mathrm{H}_{0}$ ditolak yang berarti terdapat pengaruh yang signifikan variabel bebas $\mathrm{X}_{1}$ (perhatian orang tua) terhadap variabel terikat $\mathrm{Y}$ (prestasi belajar fisika).

Menurut sintesis teori, perhatian orang tua sangat penting untuk menunjang semangat belajar anak. Sedangkan prestasi belajar fisika adalah kemampuan siswa dalam menguasai materi pokok fisikan (memahami dan dapat menjelaskan serta menyelesaikan soal-soal yang serta dapat menerapkan materi dalam kehidupan sehari-hari) setelah melakukan proses pembelajaran fisika yang yang dicatat pada setiap akhir semester di dalam buku laporan yang disebut rapor.

Dalam melakukan aktivitas belajarnya anak sangat membutuhkan perhatian orang tua, orang tua sebaiknya terus memberikan motivasi agar anaknya selalu semangat dalam belajarnya. Dari informasi kuantitatif dan teori tersebut peneliti berkesimpulan bahwa terdapat pengaruh perhatian orang tua terhadap prestasi belajar fisika.

\section{Pengaruh Motivasi Berprestasi terhadap Prestasi Belajar Fisika}

Berdasarkan Tabel 9 pengujian hipotesis diperoleh bahwa nilai $t_{\text {hitung }}=5,053$ dan Sig $=$ 0,000. Karena nilai $\mathrm{Sig}<0,05$ maka $\mathrm{H}_{0}$ ditolak yang berarti terdapat pengaruh yang signifikan variabel bebas $\mathrm{X}_{2}$ (motivasi berprestasi) terhadap variabel terikat $\mathrm{Y}$ (prestasi belajar fisika).

Menurut sintesis teori, motivasi berprestasi merupakan suatu usaha yang mendorong seseorang untuk bersaing dengan standar keunggulan, dimana standar keunggulan ini dapat berupa kesempurnaan tugas, dapat diri sendiri atau prestasi orang lain. Sedangkan prestasi belajar fisika adalah kemampuan siswa dalam menguasai materi pokok fisikan (memahamidan dapat menjelaskan serta menyelesaikan soal-soal yang serta dapat menerapkan materi dalam kehidupan sehari-hari) setelah melakukan proses pembelajaran fisika yang yang dicatat pada setiap akhir semester di dalam buku laporan yang disebut rapor.

Motivasi berprestasi merupakan salah satu faktor penentu dalam keberhasilan pendidikan. Seorang siswa akan berhasil dalam pelajarannya apabila dalam diri siswa itu ada keinginan untuk belajar. Dalam kegiatan belajar, siswa di sekolah mempelajari berbagai ilmu pengetahuan dan diusahakan agar semua siswa mendapatkan nilai yang bagus yang tentunya dapat dicapai dengan memiliki motivasi berprestasi yang tinggi. Dari informasi kuantitatif dan teori tersebut peneliti berkesimpulan bahwa terdapat pengaruh motivasi berprestasi terhadap prestasi belajar fisika.

\section{Simpulan dan Saran \\ Simpulan}

Berdasarkan pembahasan hasil penelitian, maka penelitian ini telah berhasil menjawab hipotesis yang diajukan. Dengan demikian kesimpulan dari hasil penelitian ini adalah:

1. Terdapat pengaruh perhatian orang tua dan motivasi berprestasi secara bersama-sama terhadap prestasi belajar fisika. Hal ini diperlihatkan nilai koefisien korelasi ganda sebesar 0,58 dengan kontribusi sebesar 33,6\% terhadap prestasi belajar fisika. Pengaruh ini signifikan dengan nilai sig yang diperoleh adalah sebesar 0,000 . Nilai tersebut lebih kecil dari 0,05 yang berarti pengaruhnya signifikan. Berdasarkan hal tersebut maka semakin baik perhatian orang tuadan motivasi berprestasi maka akan semakin baik juga prestasi belajar fisikanya. 
2. Terdapat pengaruh perhatian orang tua terhadap prestasi belajar fisika. Pengaruh ini signifikan dengan nilai sig yang diperoleh adalah sebesar 0,037. Nilai tersebut lebih kecil dari 0,05 yang berarti pengaruhnya signifikan. Berdasarkan hal tersebut maka semakin baik perhatian orang tua maka akan semakin baik juga prestasi belajar fisikanya.

3. Terdapat pengaruh motivasi berprestasi terhadap prestasi belajar fisika. Pengaruh ini signifikan dengan nilai sig yang diperoleh sebesar 0,000 yang lebih kecil dari 0,05. Berdasarkan hal tersebut maka semakin baik motivasi berprestasi maka akan semakin baik juga prestasi belajar fisikanya.

\section{Saran}

Berdasarkan kesimpulan yang diperoleh dalam penelitian ini menunjukkan bahwa perhatian orang tua dan motivasi berprestasi secara bersama-sama mempengaruhi prestasi belajar fisika. Oleh karena itu, penelitian ini dapat dijadikan kajian berbagai pihak terkait antara lain siswa, pendidik, dan orang tua. Sehubungan dengan pentingnya hal tersebut maka ada beberapa saran yang perlu ditindak lanjuti kepada berbagai pihak, antara lain:

1. Siswa

a. Siswa diharapkan untuk turut serta aktif dalam proses belajar mengajar dan dapat meningkatkan motivasi berprestasi pada diri sendiri agar menjadi siswa yang aktif dan kreatif dalam memperoleh ilmu pengetahuan sehingga berguna untuk masyarakat.

b. Siswa hendaknya meningkatkan kesadaran dan usahanya dalam rangka memperoleh informasi nonformal sehingga pengetahuan mereka dapat lebih bertambah wawasannya, seperti mencari informasi lewat internet, membaca koran/ buku selain buku referensi dari guru.

2. Guru

a. Guru mejadikan penelitian ini sebagai bahan kajian untuk mencapai tujuan belajar optimal, dibantu oleh lembaga atau sekolah terkait untuk lebih memperhatikan sarana dan prasarana belajar agar siswa lebih maksimal memanfaatkan sarana dan prasarana tersebut dan dapat membangun potensi yang ada dalam diri siswa.

b. Guru memperhatikan siswa untuk aktif dalam kegiatan pembelajaran, memberikan pengalaman belajar dan memotivasi siswa untuk meningkatkan prestasi belajar.

3. Orang Tua

a. Orang tua senantiasa memperhatikan putra/putrinya dalam belajar dirumah.

b. Orang tua dapat memberikan dukungan kepada anaknya dalam belajar.

\section{Daftar Pustaka}

Djaali. (2013). Psikologi Pendidikan. Jakarta: Bumi Aksara.

Depdikbud. (2006). Kamus Besar Bahasa Indonesia. Jakarta: Balai Pustaka.

Sardiman. (2011). Interaksi dan Motivasi Belajar-Mengajar. Jakarta: Rajawali Pers.

Suryabrata, Sumadi. (2008). Psikologi Pendidikan. Jakarta: PT. Raja Grafindo Persada.

Syah, Muhibbin. (2004). Psikologi Pendidikan dengan Pendekatan Baru. Bandung: PT. Remaja Rosda karya.

Uno, H. B. (2008). Pembelajaran Menciptakan Proses Belajar Mengajar yang Kreatif dan Efektif. Jakarta: Bumi Aksara.

Walgito, Bimo. (2010). Pengantar Psikologi Umum. Yogyakarta: Andi Offset. 